\title{
The Chemical Composition of the Nucleic Acids and Other Macromolecular Constituents of Mycoplasma mycoides var. capri
}

\author{
BY A. S. JONES, J. R. TITTENSOR AND R. T. WALKER \\ Department of Chemistry, Birmingham University, Edgbaston, Birmingham 15
}

(Received 12 April 1965)

\section{SUMMARY}

Samples of deoxyribonucleic acid (DNA), microsomal ribonucleic acid (RNA) and a neutral polysaccharide from Mycoplasma mycoides var. capri were isolated and analysed. The DNA was found to have an adenine +thymine/guanine + cytosine value of $3 \cdot 04$, and the RNA to have an adenine + uracil/guanine + cytosine value of $1 \cdot 21$.

The amino acid composition of the protein of the organism was also determined and found to be in close agreement with the values expected by extrapolating the curves obtained from the amino acid contents of the protein of several bacteria having DNA's with a wide range of adenine + thymine/guanine + cytosine values (Sueoka, 1961). The values were also in close agreement with those obtained for the protein of Tetrahymena pyriformis, which has a DNA of similar base composition $(\mathrm{A}+\mathrm{T} / \mathrm{G}+\mathrm{C}=\mathbf{3} \cdot \mathbf{0})$. Two significant exceptions were noted: the value for proline was almost twice as large as would have been expected and a large amount of cysteine was found.

The mycoplasma organisms contained a very small amount of a neutral polysaccharide in which only glucose was detected.

\section{INTRODUCTION}

The information available about the chemical composition of the Mycoplasmatales shows that there was little difference between the strains tested and bacteria except for a lower nucleic acid content (Lynn \& Smith, 1957), the presence of cholesterol (Lynn \& Smith, 1960; Morowitz et al. 1962) and the evidence presented in a preliminary communication (Jones \& Walker, 1963 $a$ ) that the deoxyribonucleic acid (DNA) of Mycoplasma mycoides var. capri had an adenine + thymine/guanine + cytosine ratio of 3.00. This is, as far as we are aware, the highest value found for the DNA from any micro-organism. The present communication gives more details about the isolation and analysis of the DNA and describes the isolation and analysis of the RNA and a neutral polysaccharide. The amino acid composition of the total protein of the mycoplasma organism was also determined and compared with the values obtained by Sueoka (1961) for the amino acid content of the protein from several bacteria and a protozoon.

\section{METHODS}

Organism. The strain Mycoplasma mycoides var. capri P.G. 3 was obtained from Dr D. G. ff. Edward (Wellcome Research Laboratories, Beckenham, Kent).

Medium. The organism was grown in either of the following media: (1) 'normal 
medium' containing Oxoid brain heart infusion (3.7\%, w/v), Burroughs Wellcome horse serum $(1 \%, \mathrm{w} / \mathrm{v})$, penicillin (100 units $/ \mathrm{ml}$.), thallous acetate $(0.01 \%, \mathrm{w} / \mathrm{v})$; (2) 'dilute medium' containing Oxoid brain heart infusion $(0.45 \%, w / v)$, Oxoid peptone $(1.0 \%, \mathrm{w} / \mathrm{v}), \mathrm{NaCl}(0.5 \%, \mathrm{w} / \mathrm{v})$, sodium dihydrogen phosphate $(0.25 \%$, w/v), Burroughs Wellcome horse serum $(1.0 \%, w / v)$, glucose $(0 \cdot 2 \%, w / v)$, with penicillin and thallous acetate as before.

Total phosphorus was estimated by the method of Jones, Lee \& Peacocke (1951).

Nitrogen was estimated by the method described by Jones \& Walker (1963b).

Pentose was determined by the method of Euler \& Hahn (1946) with a purified yeast nucleic acid preparation as a standard.

Deoxypentose was determined by the method of Dische (1955) with a purified calf thymus DNA preparation as a standard.

Purine and pyrimidine contents of nucleic acids. DNA samples were hydrolysed as described by Wyatt \& Cohen (1953) and the bases determined as described by Wyatt (1951). RNA samples were hydrolysed and the bases determined as described by Markham \& Smith (1951) after separating the bases in the solvent system described by Kirby (1955).

Amino acid composition of the proteins. Protein samples were hydrolysed by the method of Spackmann, Stein \& Moore (1958), and the amino acid composition was analysed by a Technicon Automatic Amino Acid Analyser.

Hydrolysis of the polysaccharide. The polysaccharide was hydrolysed for $3 \mathrm{hr}$ at $100^{\circ}$ in M-sulphuric acid, and neutralized with barium hydroxide. The monosaccharide components were detected and identified chromatographically.

\section{RESULTS}

\section{Growth and harvesting of organisms}

Growth curves were obtained for the organisms when they were grown in the 'normal' and in the 'dilute' medium. The results showed that maximum opacity of the solution was obtained in the 'normal' medium after incubation for $18 \mathrm{hr}$, but about $36 \mathrm{hr}$ were needed in the case of the 'dilute 'medium. The maximum opacities reached in the two media were similar and the same yield of organisms was obtained from the same quantity of the two media. The organism was grown in $300 \mathrm{ml}$. medium in a $1 \mathrm{l}$. bottle which was inoculated with a $48 \mathrm{hr}$ culture $(2 \mathrm{ml}$.$) and$ incubated at $37^{\circ}$ for $18 \mathrm{hr}$ in normal medium, or $42 \mathrm{hr}$ in dilute medium. The organisms were harvested at $11,600 \mathrm{rev} . / \mathrm{min}$. in a continuous-flow refrigerated centrifuge (Measuring \& Scientific Equipment Ltd.). When harvesting the organisms from the dilute medium it was found necessary to cool the suspension to $0^{\circ}$ before centrifugation to prevent enzymic degradation of the nucleic acid. This was achieved by passing the suspension through polythene tubing $(2000 \mathrm{~cm} . \times 1 \mathrm{~cm}$.) immersed in an ice + salt cooling mixture. No pre-cooling was necessary when the organism was grown in the normal medium.

\section{Isolation of the RNA,DNA and a neutral polysaccharide}

The organisms from $20 \mathrm{l}$. medium were added to a phenol solution saturated with water $(100 \mathrm{ml}$.) and sodium $p$-aminosalicylate solution $(6 \%, \mathrm{w} / \mathrm{v} ; 100 \mathrm{ml}$.) and the mixture shaken for $1 \mathrm{hr}$ at $4^{\circ}$. The nucleic acids and polysaccharide were precipi- 
tated from the aqueous layer by the addition of ethanol ( 3 vol.) and the phenol layer and cell debris were re-extracted with salicylate solution until no more material precipitable with 3 vol. of ethanol was obtained; usually five extractions were necessary. The combined ethanol precipitates were dissolved in water $(100 \mathrm{ml}$.) and centrifuged at $105,000 \mathrm{~g}$ (Spinco ultracentrifuge) for $\mathbf{3 0} \mathrm{min}$. to remove cell debris; the supernatant fluid was then made $\mathrm{M}$ with respect to $\mathrm{NaCl}$ and allowed to stand at $0^{\circ}$ for $18 \mathrm{hr}$. The precipitate was removed by centrifugation at $105,000 \mathrm{~g}$ for $30 \mathrm{~min}$., washed with $\mathrm{M}-\mathrm{NaCl}$, dissolved in water, dialysed and freeze-dried to give RNA (20 mg., probably microsomal).

To the supernatant fluid from the RNA precipitate, ethanol (3 vol.) was added and the resulting precipitate dissolved in $0 \cdot 1 \mathrm{M}-\mathrm{NaCl}$. Cetyltrimethylammonium bromide (CTAB, British Drug Houses Ltd., $5 \%$, w/v) was added until precipitation of acidic material was complete and the precipitate centrifuged down. Ethanol ( 3 vol.) was added to the supernatant fluid to precipitate the neutral polysaccharide, which was centrifuged down, separated and dissolved in water. Contaminating CTAB was removed by shaking with chloroform ( 3 times), and the aqueous solution dialysed and freeze-dried to give the polysaccharide $(3 \mathrm{mg}$.).

The material precipitated with $\mathrm{CTAB}$ was dissolved in $\mathrm{M}-\mathrm{NaCl}(20 \mathrm{ml}$.), CTAB added to the solution so that its final concentration was $1 \%(\mathrm{w} / \mathrm{v})$, and the concentration of the $\mathrm{NaCl}$ decreased to $0.6 \mathrm{M}$ by adding water $(13.3 \mathrm{ml}$.), the temperature being kept at about $20^{\circ}$. The cetyltrimethylammonium salt of DNA which precipitated was removed and dissolved in $\mathrm{M}-\mathrm{NaCl}$, ethanol (3 vol.) was added and the resulting precipitate was dissolved in water, extracted with chloroform to remove cetyltrimethylammonium salts and the aqueous solution dialysed and freeze-dried to give DNA (16.5 mg.).

\section{Composition of the $D N A$}

The DNA was isolated in three separate experiments. The base contents of the samples are shown in Table 1. The RNA and protein contents of all samples were less than $1 \%$. Phosphorus content was $8.9 \%(w / w)$, the nitrogen to phosphorus ratio $1 \cdot 69(\mathrm{w} / \mathrm{w})$ and the extinction of a solution containing $1 \mathrm{~g}$. atom phosphorus/l. at $\mathrm{pH} \mathrm{7.0}$ was 7500 at $260 \mathrm{~m} \mu$.

Table 1. Base composition of the DNA of Mycoplasma mycoides var. capri, P.G. 3

I and II DNA isolated from organisms grown on 'normal' medium. III DNA isolated from organisms grown on 'dilute' medium. Other bases, particularly 5-methylcytosine and 6-methylaminopurine, were not detected. The amounts were determined from the ultraviolet absorption of the eluate from paper chromatograms after hydrolysis of the DNA in formic acid. The amounts are given in moles base/100 g. atoms $P$ (corrected to $100 \%$ recovery of phosphorus; recovery was 90-95\%).

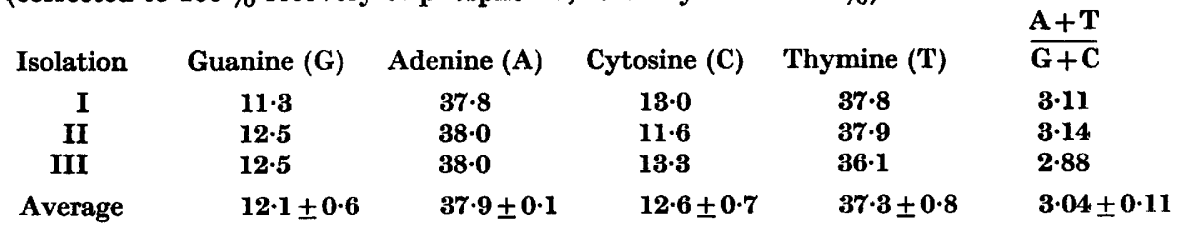

\section{Composition of the $R N A$}

The RNA was isolated in three separate experiments. The base contents of the samples are shown in Table 2. 
Table 2. Base composition of the RNA of Mycoplasma mycoides var. capri, P.G. 3

All samples were from organisms grown in the dilute medium. The amounts were determined from the ultraviolet absorption of the eluate from paper chromatograms after hydrolysis of the RNA in hydrochloric acid. The amounts are given in moles base/ $100 \mathrm{~g}$. atoms $P$ (see Table 1).

\begin{tabular}{|c|c|c|c|c|c|}
\hline Isolation & Guanine (G) & Adenine (A) & Cytosine (C) & Uracil (U) & $\frac{\mathbf{A}+\mathbf{U}}{\mathbf{G}+\mathbf{C}}$ \\
\hline $\mathbf{I}$ & $25 \cdot 7$ & $29 \cdot 8$ & $19 \cdot 8$ & 24.7 & $1 \cdot 20$ \\
\hline II & $25 \cdot 5$ & $31 \cdot 0$ & $19 \cdot 4$ & $24 \cdot 1$ & $1 \cdot 23$ \\
\hline III & $25 \cdot 9$ & $30 \cdot 3$ & $19 \cdot 2$ & $24 \cdot 5$ & $1 \cdot 21$ \\
\hline Average & $25 \cdot 7 \pm 0 \cdot 2$ & $30 \cdot 4 \pm 0.5$ & $19 \cdot 5 \pm 0.2$ & $24 \cdot 5 \pm 0 \cdot 3$ & $1 \cdot 21 \pm 0 \cdot 1$ \\
\hline
\end{tabular}

Table 3. Amino acid composition of the total protein of Mycoplasma mycoides var. capri, P.G. 3

The protein was hydrolysed with $5 \mathrm{~N}-\mathrm{HCl}$ in vacuo at $110^{\circ}$ for $22 \mathrm{hr}$. The amino acid composition was analysed by a Technicon Automatic Amino Acid Analyser. The results are expressed in the same form as those quoted by Sueoka (1961) and his values for the amino acid composition of the protein of Tetrahymena pyriformis are given for comparison. Molar amounts of amino acids lysine, histidine, arginine, aspartic acid and asparagine, glutamic acid and glutamine, proline, alanine, valine, leucine, tyrosine and phenylalanine, which are known to be stable and to be well recoverable in the analysis, were summed. The other amino acids are classified as unstable amino acids. The amount of each amino acid both stable and unstable is expressed by its proportion to the sum of the stable amino acids.

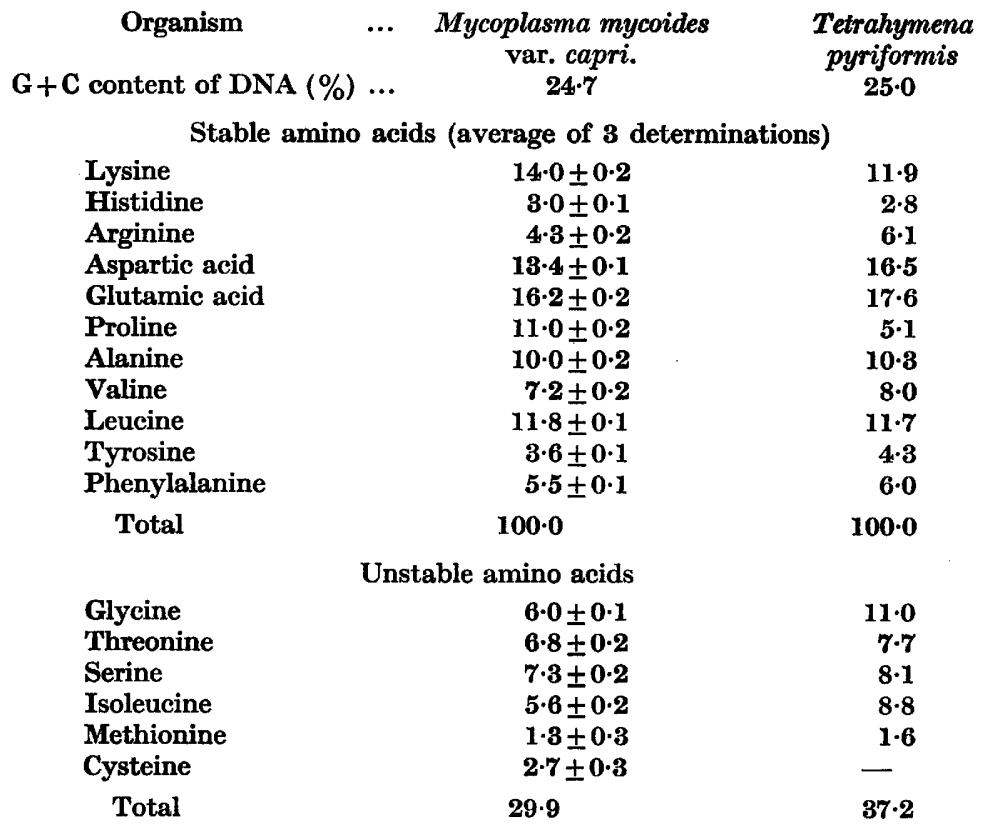




\section{Composition of the polysaccharide}

The neutralized hydrolysate of the polysaccharide was added to chromatography papers, which were developed in three solvents. Apart from a trace of D-ribose from contaminating RNA only one spot was detected with the aniline hydrogen phthalate spray for reducing sugars (Partridge, 1949), and with the silver nitrate spray, which is a non-specific detecting reagent (Trevelyan, Procter \& Harrison, 1950). The $\boldsymbol{R}_{\boldsymbol{F}}$ values of the compound in the solvent systems were: in $n$-butanol + ethanol + water $\left(4+1+5\right.$, by vol.) $R_{\boldsymbol{r}} 0 \cdot 14\left(R_{\boldsymbol{F}}\right.$ glucose $\left.0 \cdot 14\right)$; in $n$-butanol + acetic acid + water $\left(4+1+5\right.$, by vol.) $R_{F} 0 \cdot 18\left(R_{F}\right.$ glucose $\left.0 \cdot 18\right)$; in pyridine + amyl alcohol + water $\left(1+1+1\right.$, by vol.) $R_{F} 0 \cdot 35\left(R_{F}\right.$ glucose $\left.0 \cdot 35\right)$. The compound and the glucose marker gave identically coloured spots with the two detecting reagents, and the three solvent systems used ensured that all the possible hexoses would be separated.

\section{Isolation of and determination of the amino acid content of the protein of Mycoplasma mycoides var. capri}

Mycoplasma organisms which had been grown in 11 . dilute medium were removed by centrifugation at $5000 \mathrm{~g}$, washed with physiological saline solution ( 3 times) and added to tris magnesium buffer $\left(10^{-2} \mathrm{M}\right.$-tris, $10^{-3} \mathrm{M}$-magnesium; $\mathrm{pH} \mathrm{7.3;10} \mathrm{ml.)}$ and phenol saturated with water $(10 \mathrm{ml}$.). The mixture was shaken for $1 \mathrm{hr}$, the phenol extracted with ether and the remaining aqueous suspension exhaustively dialysed. The protein suspension (0.5 ml.) was then heated in a sealed tube in vacuo with $\mathrm{HCl}\left(10 \mathrm{~N} ; 0.5 \mathrm{ml}\right.$.) at $110^{\circ}$ for $22 \mathrm{hr}$. The resulting solution was filtered free from carbon, evaporated to dryness, dissolved in $\mathrm{HCl}(0.1 \mathrm{~N} ; 2.5 \mathrm{ml}$.) and samples $(0.25 \mathrm{ml}$.) taken for amino acid analysis. The results are given in Table 3; they are expressed in the same forms as those quoted by Sueoka (1961) and his values for the amino acid composition of the protein of Tetrahymena pyriformis are given for comparison.

\section{DISCUSSION}

In previous cases when base analyses have been quoted for the nucleic acids of the Mycoplasmatales (Lynn \& Smith, 1957; Morowitz et al. 1962), the nucleic acids have either been analysed in the presence of other cellular constituents or degraded samples have been used. It has now been found possible to isolate samples of pure highly polymerized nucleic acids from Mycoplasma mycoides var. capri.

The expense of the normal medium was too great to allow the organism to be grown in the large volumes required to isolate sufficient nucleic acid to analyse (20 1.), so another (dilute) medium was found which gave the same yield of organism/l. medium but which contained only $12 \%$ of the normal brain heart infusion content. With large volumes $(201$.) it was necessary to cool the suspension of organisms when grown in the dilute medium before centrifugation in order to prevent enzymic degradation during the time taken for the centrifugation. When this precaution was not taken degradation of the DNA occurred, so preventing precipitation of its cetyltrimethylammonium salt in $0 \cdot 6 \mathrm{M}-\mathrm{NaCl}$ and hence preventing the separation of the DNA from the RNA.

The isolation and separation of the nucleic acids and neutral polysaccharide followed closely the method reported previously for Serratia marcescens (Jones \& Walker, 1963b). As the Mycoplasmatales have no rigid cell wall the phenol was 
sufficient to rupture the cells and to liberate the nucleic acids and polysaccharide into the aqueous layer and also to prevent enzymic degradation.

The base analysis of the DNA shows that it contained more adenine and thymine than any bacterial DNA so far analysed. The only DNA to have a comparable base analysis is that from the protozoon, Tetrahymena pyriformis. The $\mathrm{A}+\mathrm{T} / \mathrm{G}+\mathrm{C}$ ratio of 3.04 for Mycoplasma mycoides var. capri P.G. 3 has recently been confirmed by caesium sulphate density centrifugation technique ( $\mathrm{Dr}$ W. Szybalski, personal communication). As previously remarked (Jones \& Walker, 1963a) it is very unlikely that $M$. mycoides var. capri is an $\mathrm{L}$ form of a bacterium the composition of whose DNA is known; the present analysis lends support to the idea that the Mycoplasmatales are a distinct group.

The RNA base analysis shows that the RNA also contained more adenine and uracil than do most RNA's, although the moles of 6-amino bases equal the number of moles of 6-keto bases. Tetrahymena pyriformis has an RNA with a similar composition (Scherbaum, 1957).

Sueoka (1961) found a correlation between the amino acid content of the proteins and the guanine + cytosine $(\mathrm{G}+\mathrm{C})$ content of the bacterial DNA's examined. The values obtained here for the amino acid composition of the protein of Mycoplasma mycoides var. capri agree with the values expected from the curves obtained by Sueoka (1961) and also for those obtained for Tetrahymena pyriformis, which has a DNA of almost identical base composition. In the list of stable amino acids, all fit the curves as well as or better than the values for $T$. pyriformis, with the exception of proline. Sueoka (1961) found that the amount of proline decreased with decreasing $\mathbf{G}+\mathbf{C}$ content. The value obtained in the present work is almost twice the expected proline content of an organism with an extreme $\mathbf{G}+\mathbf{C}$-containing DNA. This difference might be attributed to the fact that in the present case the amino acid content of the whole organism was determined, whereas Sueoka used purified fractions and rejected cell wall and possibly cytoplasmic membrane as well. Although $M$. mycoides var. capri has no cell wall, the membrane constituents would be present, and these might have a high proline content. It is also possible that structures of this type may be produced in a way that does not depend directly on a DNA template (e.g. the capsule of Bacillus anthracis; Salton 1960).

It is difficult to show correlations between the values obtained for the unstable amino acids since the amounts of these which are present depend to a large extent on the nature of any material contaminating the protein and on the exact conditions of hydrolysis. The amount of glycine observed was rather low, but, since it is known that this amino acid can arise from the degradation of the bases in any contaminating nucleic acids (Fraser, 1957), no significance can be attached to this. The only other amino acid content to differ significantly from that in bacteria was that of cysteine, which is usually not detectable but was present in quite large amounts in the protein of $M$. mycoides var. capri.

The polysaccharide of a bovine pleuropneumonia-like organism was investigated by Plackett \& Buttery (1958), who found a galactan comprising about $10 \%$ of the dry weight of the organism. No evidence for the presence of galactose or any other sugar apart from glucose was found in the neutral polysaccharide fraction of $M$. mycoides var. capri examined in the present work and this polysaccharide only comprised about $0.5 \%$ of the dry weight of the organisms. 
The authors thank Professor M. Stacey, F.R.S., for his interest, Mr E. T. J. Chelton for technical assistance, and the British Empire Cancer Campaign for financial assistance.

\section{REFERENCES}

Dische, Z. (1955). Color reactions of nucleic acid components. In The Nucleic Acids, 1, 285. Ed. by E. Charaff \& J. N. Davidson. New York: Academic Press.

Euler, H. \& HaHN, L. A. (1946). A new method for the quantitative determination of ribonucleic acid in animal tissues. Svensk. kem. Tidskr. 10, 251.

Fraser, D. (1957). Comparison of the amino acid composition of T2 and T3 bacteriophages. J. biol. Chem. 227, 711.

Jones, A. S., Lee, W. A. \& Peacocke, A. R. (1951). The determination of phosphorus in deoxypentose nucleic acids. J. chem. Soc. p. 623.

Jones, A. S. \& WALKer, R. T. (1963a). Isolation and analysis of the deoxyribonucleic acid of Mycoplasma mycoides var. capri. Nature, Lond. 198, 588.

Jones, A. S. \& WALkER, R. T. (1963b). Studies on the deoxyribonucleic acid of Serratia marcescens. J. gen. Microbiol. 31, 187.

KIRBY, K. S. (1955). Some new solvent systems for the paper chromatography of nucleic acid degradation products. Biochim. biophys. Acta, 18, 575.

LyNN, R. J. \& Smith, P. F. (1957). Nucleic acid content of pleuropneumonia-like organisms from human sources. J. Bact. 74, 811.

Lynn, R. J. \& Smith, P. F. (1960). Chemical composition of PPLO. Ann. N.Y. Acad. Sci. 79, 493.

Markham, R. \& SMith, J. D. (1951). Chromatographic studies of nucleic acids. 4. The nucleic acids of the tobacco yellow mosaic virus including a note on the nucleic acids of the tomato bushy stunt virus. Biochem. J. 49, 401.

Morowitz, H. J., Tourtellotte, M. E., Guild, W. R., Castro, E., Woese, C. \& Cleverdon, R. C. (1962). The chemical composition and submicroscopic morphology of Mycoplasma gallisepticum, avian PPLo 5969. J. molec. Biol. 4, 93.

Partridge, S. M. (1949). Aniline hydrogen phthalate as a spraying reagent for chromatography of sugars. Nature, Lond. 164, 443.

Plackett, P. \& Buttery, S. H. (1958). A galactan from Mycoplasma mycoides. Nature, Lond. 182, 1236.

Salton, M. R. J. (1960). Surface layers of the bacterial cell. In The Bacteria, 1, 105. Ed. by I. C. Gunsalus \& R. R. Stanier. New York: Academic Press.

Scherbaum, O. (1957). The content and composition of nucleic acids in normal and synchronously dividing mass cultures of Tetrahymena pyriformis. Exptl Cell Res. 13, 24.

Spackmann, D. H., Stein, W. H. \& Moore, S. (1958). Automatic recording apparatus for use in the chromatography of amino acids. Anal. Chem. 30, 1190.

Sucoka, N. (1961). Correlation between base composition of deoxyribonucleic acid and amino acid composition of protein. Proc. natn. Acad. Sci. U.S.A. 47, 1141.

Trevelyan, W. E., Procter, D. P. \& Harrison, J. S. (1950). Detection of sugars on paper chromatograms. Nature, Lond. 166, 444.

WYatt, G. R. (1951). The purine and pyrimidine composition of deoxypentosenucleic acids. Biochem. $J, 48,584$.

WyatT, G. R. \& Cohen, S. S. (1953). The bases of the nucleic acids of some bacterial and animal viruses: the occurrence of 5-hydroxymethylcytosine. Biochem. J. 55, 774. 